\title{
Purification of $A_{1}$ adenosine receptor-G-protein complexes: effects of receptor down-regulation and phosphorylation on coupling
}

\author{
Zhenhai GA0*, Anna S. ROBEVA* and Joel LINDEN* ${ }^{*}$ \\ *Department of Molecular Physiology and Biological Physics, Health Sciences Center Box 449, University of Virginia, Charlottesville, VA 22908, U.S.A., and †Department \\ of Internal Medicine, Health Sciences Center Box MR4 6012, University of Virginia, Charlottesville, VA 22908, U.S.A.
}

We examined the effects of exposing $A_{1}$ adenosine receptors $\left(\mathrm{A}_{1} \mathrm{ARs}\right)$ to an agonist on the stability and phosphorylation state of receptor-guanine nucleotide-binding regulatory protein $(\mathrm{R}-\mathrm{G}-$ protein) complexes. Non-denatured recombinant human $\mathrm{A}_{1} \mathrm{ARs}$ extended on the $\mathrm{N}$-terminus with hexahistidine $\left(\mathrm{His}_{6}\right)$ and the FLAG (Asp-Tyr-Lys-Asp-Asp-Asp-Asp-Lys) epitope (H/F) were purified to near homogeneity from stably transfected Chinese-hamster ovary (CHO)-K1 cells. Purified receptors have pharmacological properties similar to receptors in membranes. G-proteins were co-purified with $15 \pm 2 \%$ of $\mathrm{H} / \mathrm{F}-\mathrm{A}_{1} \mathrm{AR}$ unless receptor-G-protein $(\mathrm{R}-\mathrm{G})$ complexes were uncoupled by pretreating cell membranes with GTP. By silver staining, purified $\mathrm{A}_{1} \mathrm{AR}-\mathrm{G}$-protein complexes contain receptors, G-protein $\alpha$ and $\beta$ subunits and an unidentified $97 \mathrm{kDa}$ protein. Pretreating intact cells with $N^{6}$-cyclopentyladenosine (CPA) for $24 \mathrm{~h}$ decreased both the total number of receptors measured in membranes and the number of purified $\mathrm{A}_{1} \mathrm{ARs}$ by about $50 \%$. In contrast, pretreating cells with CPA decreased the number of $\mathrm{R}-\mathrm{G}$ complexes measured in membranes $(54 \pm 6 \%)$ significantly less than it decreased the number of purified $\mathrm{R}-\mathrm{G}$ complexes $(78 \pm 3 \%)$ as detected by ${ }^{125} \mathrm{I}-N^{6}-(4$-aminobenzyl)adenosine binding or by Western blotting $\mathrm{G}_{i} \alpha 2$. The effect of CPA to decrease the fraction of receptors purified as $\mathrm{R}-\mathrm{G}$ complexes was not associated with any change in low-level $\mathrm{A}_{1} \mathrm{AR}$ phosphorylation (found on serine), or low-level phosphorylation of Gprotein $\alpha$ or $\beta$ subunits or the $97 \mathrm{kDa}$ protein. These experiments reveal a novel aspect of agonist-induced down-regulation, namely a diminished stability of receptor-G-protein complexes that is manifested as uncoupling during receptor purification.

Key words: desensitization, FLAG, hexahistidine, purinergic, signalling.

\section{INTRODUCTION}

Heterotrimeric G-proteins of the $\mathrm{G}_{\mathrm{i} / \mathrm{o}}$ family are tightly coupled to heptahelical receptors in the rhodopsin family. Hence, when agonist affinity chromatography has been used to purify $A_{1}$ adenosine receptors ( $\left.A_{1} A R s\right), G_{i} \propto 1, G_{i} \alpha 2$ and $G_{0} \propto$ were copurified from bovine brain [1,2]. Similarly, $\mathrm{G}_{i} \alpha 1, \mathrm{G}_{\mathrm{i}} \propto 3$ and $\mathrm{G} \beta_{36}$ were co-purified with agonist-occupied somatostatin receptors [3]. Using lectin affinity chromatography or co-immunoprecipitation techniques, $G_{i / 0}$ proteins were co-purified with receptors for formylpeptide chemoattractant [4], $\mu$ - and $\delta$-opioid [5], heart and brain muscarinic [6], C5a [7] and AT2 angiotensin [8].

Ligand affinity chromatography or immunoprecipitation generally results in a low yield of purified receptors. Higher-efficiency receptor purification has been achieved recently using receptors genetically engineered to facilitate purification. Recombinant human adenosine receptors were double-tagged with hexahistidine $\left(\mathrm{His}_{6}\right.$ ) and the FLAG epitope (Asp-Tyr-Lys-Asp-AspAsp-Asp-Lys) (H/F) and purified to near homogeneity by sequential anti-FLAG-antibody and Ni-nitrilotriacetate (NTA)affinity-chromatography steps [9]. Of the four G-protein-coupled adenosine receptors that have been cloned $\left(\mathrm{A}_{1}, \mathrm{~A}_{2 \mathrm{~A}}, \mathrm{~A}_{2 \mathrm{~B}}\right.$ and $\mathrm{A}_{3}$ [10]), the $A_{1}$ and the $A_{3}$ receptors are coupled to the $G_{i / o}$ subfamily of G-proteins. In the present study we show that nondenatured $\mathrm{A}_{1} \mathrm{ARs}$ can be purified to near homogeneity and that, by altering the coupling of $A_{1} A R s$ to $G$-proteins before their solubilization and purification, $\mathrm{H} / \mathrm{F}-\mathrm{A}_{1} \mathrm{ARs}$ can be purified with or without associated G-proteins.
Long-term exposure of G-protein-coupled receptors (GCRs) to agonists results in uncoupling of receptors from G-proteins. With continued agonist exposure the number of receptors is down-regulated $[11,12]$. Desensitization of GCRs is sometimes, but not always, preceded by receptor phosphorylation [13]. The $\mathrm{A}_{1} \mathrm{AR}$ is controversial in this regard because it desensitizes slowly and there are conflicting reports about whether it is phosphorylated after exposure to an agonist (see the Discussion section). In the present study we confirmed that $\mathrm{A}_{1} \mathrm{ARs}$ desensitize slowly $\left(t \frac{1}{2}>5 \mathrm{~h}\right)$ and we show that receptor-G-protein $(\mathrm{R}-\mathrm{G})$ complexes derived from desensitized cells are prone to become uncoupled during purification. Highly purified $\mathrm{H} / \mathrm{F}$ $\mathrm{A}_{1} \mathrm{ARs}$ that are unequivocally identified as receptors based on a characteristic shift in their electrophoretic mobility following deglycosylation are only weakly phosphorylated on serine residues. Although we detect low-level phosphorylation of the $A_{1} A R$, G-protein $\alpha$ and $\beta$ subunits and a co-purified $97 \mathrm{kDa}$ protein, we conclude that phosphorylation of these proteins is not responsible for the destabilization of $\mathrm{R}-\mathrm{G}$ complexes that occurs following long-term exposure of $\mathrm{A}_{1} \mathrm{ARs}$ to an agonist.

\section{EXPERIMENTAL}

\section{Materials}

$N^{6}$-Cyclopentyladenosine (CPA), 5'- $N$-ethylcarboxamidoadenosine (NECA), 9-chloro-2-(2-furyl)-5,6-dihydro[1,2,4]triazolo[1,5-c]quinazoline-5-imine (CGS21680), xanthine amine con-

Abbreviations used: $A_{1} A R, A_{1}$ adenosine receptor; ADA, adenosine deaminase; FLAG (epitope), Asp-Tyr-Lys-Asp-Asp-Asp-Asp-Lys; H/F, His 6 -FLAG; ABA, $\quad N^{6}$-(4-aminobenzyl)adenosine; azido-BW-A844, 8-cyclopentyl-3-azidophenethyl-1-propylxanthine; CPA, $N^{6}$-cyclopentyladenosine; CPX, 8cyclopentyl-1,3-dipropylxanthine; CGS15943, 9-chloro-2-(2-furyl)-5,6-dihydro[1,2,4]triazolo[1,5-c]quinazoline-5-imine; GCR, G-protein-coupled receptor; GRK, G-protein-coupled receptor kinase; CHO, Chinese-hamster ovary; R-G, receptor-G-protein (complex); GTP[S], guanosine 5'-[ $\gamma$-thio]triphosphate; DMEM, Dulbeccco's modified Eagle's medium; NTA, nitrilotriacetate.

To whom correspondence should be addressed (e-mail jlinden@virginia.edu). 
gener (8-\{4-[(2-aminoethyl)aminocarbonylmethoxy]phenyl\}-1,3dipropylxanthine (XAC) and 8-sulphophenyltheophylline (8SPT) were purchased from Research Biochemicals International (Natick, MA, U.S.A.); 8-cyclopentyl-1,3-dipropylxanthine (CPX) and $N^{6}$-(4-aminobenzyl)adenosine (ABA) were gifts from Dr. Susan Daluge of Glaxo Wellcome (Research Triangle Park, NC, U.S.A.). $\left[{ }^{3} \mathrm{H}\right] \mathrm{CPX}$ was from New England Nuclear (Boston, MA, U.S.A.); tissue-culture reagents were from Gibco-BRL (Grand Island, NY, U.S.A.); adenosine deaminase and N-glycosidase $F$ from Boehringer Mannheim Biochemicals (Indianapolis, IN, U.S.A.); FLAG peptide and anti-FLAG $\mathrm{m} 2$ affinity gel from Kodak IBI (New Haven, CT, U.S.A.); NiNTA-agarose from Qiagen (Chatsworth, CA, U.S.A.); enhanced chemiluminescence reagent and hyper-film MP from Amersham (Arlington Heights, IL, U.S.A.); centricon-30 concentrators from Amicon (Beverly, MA, U.S.A.); digitonin from GallardSchlesinger Industries (Carle Place, NY, U.S.A.). The synthesis and purification of ${ }^{125} \mathrm{I}-\mathrm{ABA}[14]$ and the preparation of stably transfected cells with $\mathrm{His}_{6} /$ FLAG-tagged human $\mathrm{A}_{1}$ ARs $(\mathrm{H} / \mathrm{F}$ $\mathrm{A}_{1} \mathrm{ARs}$ ) [9] have been described previously.

\section{Cell culture and membrane preparation}

Chinese-hamster ovary (CHO)-K1 cells stably transfected with $\mathrm{H} / \mathrm{F}-\mathrm{A}_{1} \mathrm{ARs}$ were grown in Ham's F12 medium supplemented with $10 \%$ fetal bovine serum, 100 units $/ \mathrm{ml}$ penicillin, $100 \mu \mathrm{g} / \mathrm{ml}$ streptomycin and $0.5 \mathrm{mg} / \mathrm{ml} \mathrm{G} 418$. In some instances cells were exposed to $20 \mu \mathrm{M}$ CPA for various times. Cell monolayers were washed with PBS $(3 \times 10 \mathrm{ml}$ after incubation with CPA $)$ and harvested in buffer A (10 mM Hepes/20 mM EDTA, pH 7.4), supplemented with protease inhibitors $(20 \mu \mathrm{g} / \mathrm{ml}$ benzamidine, $100 \mu \mathrm{M}$ PMSF and $2 \mu \mathrm{g} / \mathrm{ml}$ each of aprotinin, pepstatin and leupeptin). The cells were homogenized, centrifuged at $30000 \mathrm{~g}$ and washed twice with buffer HE (10 mM Hepes/1 mM EDTA, $\mathrm{pH}$ 7.4) containing protease inhibitors. The pellet was resuspended in $\mathrm{HE}$ and used immediately or frozen in aliquots at $-80{ }^{\circ} \mathrm{C}$.

\section{Solubilization and purification of G-protein-coupled or uncoupled H/F-A AR}

CHO-K1 cell membranes were resuspended in buffer B $(25 \mathrm{mM}$ Hepes/ $150 \mathrm{mM} \mathrm{NaCl}, \mathrm{pH} 7.4)$ supplemented with $1 \mu \mathrm{M}$ adenosine. For purification of receptors nearly free of G-proteins, the resuspended membranes were incubated with $10 \mathrm{mM}$ GTP for $1 \mathrm{~h}$ at $21^{\circ} \mathrm{C}$. In preliminary experiments this concentration of GTP was found to be sufficient to produce maximal uncoupling. Digitonin was added at a detergent-to-membrane protein ratio of $2: 1$ and incubated on ice with rocking for $1 \mathrm{~h}$. The solubilized receptors were collected after centrifugation at $100000 \mathrm{~g}$ for $1 \mathrm{~h}$, and the detergent concentration was decreased to $0.1 \%$ by adding buffer $\mathrm{B}$. The receptors were loaded on to a $1 \mathrm{ml}$ anti(FLAG M2) affinity column, washed with $3 \times 12 \mathrm{ml}$ of buffer $\mathrm{C}$ (buffer B, containing $0.1 \%$ digitonin) and eluted in $5 \times 1 \mathrm{ml}$ fractions with buffer $\mathrm{C}$ containing $400 \mu \mathrm{g}$ of FLAG peptide. In most instances receptors from pooled fractions 2, 3 and 4 were applied to a $1 \mathrm{ml} \mathrm{Ni-NTA} \mathrm{affinity} \mathrm{column,} \mathrm{washed} \mathrm{with} \mathrm{three}$ column vol. of buffer $\mathrm{C}$, containing $1 \mathrm{mM}$ imidazole, and eluted with buffer $\mathrm{C}$ supplemented with $250 \mathrm{mM}$ imidazole, $\mathrm{pH}$ 7.4.

\section{Photoaffinity labelling of H/F-A AR}

Membranes of CHO-K1 cells expressing $\mathrm{H} / \mathrm{F}-\mathrm{A}_{1} \mathrm{AR}$ were incubated in dim light with $1 \mathrm{nM}{ }^{125}$ I-azido-BW-A844 (a xanthine photoaffinity label) at room temperature for $1.5 \mathrm{~h}$ in the presence of $10 \mu \mathrm{M}$ guanosine $5^{\prime}$-[ $\gamma$-thio]triphosphate (GTP[S]). The membranes were then irradiated with UV light for $15 \mathrm{~min}$ and centrifuged at $10000 \mathrm{~g}$ for $30 \mathrm{~min}$. The resultant pellet was resuspended in $2 \times$ buffer $C$. After solubilization, the photoaffinity-labelled $\mathrm{H} / \mathrm{F}-\mathrm{A}_{1} \mathrm{ARs}$ were purified by anti-FLAG affinity chromatography as described above.

\section{Protein phosphorylation studies}

Transfected CHO-K1 or HEK-293 cells expressing the H/F$\mathrm{A}_{1} \mathrm{AR}$ from confluent $100 \mathrm{~mm}$ plates were washed with $2 \times$ $10 \mathrm{ml}$ of phosphate-free Dulbeccco's modified Eagle's medium (DMEM) and incubated in the same medium at $37^{\circ} \mathrm{C}$, under $5 \%$ $\mathrm{CO}_{2}$, for $45 \mathrm{~min}$. The medium was replaced with $5 \mathrm{ml}$ of phosphate-free DMEM containing 1 unit $/ \mathrm{ml}$ adenosine deaminase $(\mathrm{ADA})$ and $\approx 0.8 \mathrm{mCi} / \mathrm{ml}\left[{ }^{32} \mathrm{P}\right] \mathrm{P}_{\mathrm{i}}$, and the cells were incubated at $37^{\circ} \mathrm{C}$, under $5 \% \mathrm{CO}_{2}$, for $2 \mathrm{~h}$. Cells were then treated for $12 \mathrm{~h}$ with $\mathrm{CPX}(1 \mu \mathrm{M}), \mathrm{CPA}(10 \mu \mathrm{M})$ or vehicle $(0.1 \%$ DMSO), washed with ice-cold PBS containing protease and phosphatase inhibitors $(0.18 \mathrm{mg} / \mathrm{ml}$ vanadate, $2.1 \mathrm{mg} / \mathrm{ml}$ $\mathrm{NaF}, 21.2 \mathrm{mg} / \mathrm{ml}$ glycerol $\alpha, \beta$-phosphate, and $1 \mathrm{nM}$ okadaic acid). Following the addition of solubilization buffer $(25 \mathrm{mM}$ Hepes/150 $\mathrm{mM} \mathrm{NaCl} / 2 \%$ digitonin/protease and phosphatase inhibitor cocktail) and centrifugation at $100000 \mathrm{~g}$ for $1 \mathrm{~h}, \mathrm{R}-\mathrm{G}$ complexes were purified by anti-FLAG affinity chromatography as described above and phosphoproteins analysed by SDS/ PAGE and autoradiography. Some samples were deglycosylated (see below).

\section{Phosphoamino acid analysis}

${ }^{32} \mathrm{P}$-labelled proteins were resolved by SDS/PAGE and transferred to Immobilon-P (PVDF membranes). Regions of the PVDF that contain ${ }^{32} \mathrm{P}$-labelled deglycosylated receptors were identified by autoradiography, cut out and placed in screw-cap microcentrifuge tubes. After a quick rinse in methanol, 200 $300 \mu \mathrm{l}$ of $5.7 \mathrm{M} \mathrm{HCl}$ was added and the tubes were capped and incubated for $1 \mathrm{~h}$ at $110^{\circ} \mathrm{C}$. The hydrolysed samples were dried in a centrifugal vacuum concentrator and resuspended in 5-10 $\mu 1$ of $\mathrm{pH} 1.9$ buffer $[7.8 \%(\mathrm{v} / \mathrm{v})$ acetic acid $/ 2.5 \%(\mathrm{v} / \mathrm{v})$ formic acid] containing $0.5-1 \mu \mathrm{g}$ of unlabelled phosphoamino acid standards. The tubes were centrifuged briefly at room temperature to remove particulate debris and spotted on TLC plates dampened in $\mathrm{pH} 2.5$ electrophoresis buffer $[5.9 \%(\mathrm{v} / \mathrm{v})$ acetic acid $/ 0.8 \%$ (v/v) formic acid $/ 0.3 \%$ (v/v) pyridine $/ 0.3 \mathrm{mM}$ EDTA]. The samples were electrophoresed for 45-60 min at a constant $750 \mathrm{~V}$, air-dried under a fan for $20 \mathrm{~min}$, sprayed with $0.25 \%$ ninhydrin in acetone, and dried at $65^{\circ} \mathrm{C}$ for $15 \mathrm{~min}$. The plates were exposed to $\mathrm{X}$-ray films using intensifying screens at $-70^{\circ} \mathrm{C}$ for 2 days.

\section{SDS/PAGE, Western-blot analysis and silver staining}

Aliquots from the anti-FLAG affinity or Ni-NTA affinity chromatography were loaded on to $1.5 \mathrm{~mm}$-thick SDS/12\%polyacrylamide gels and electrophoresed at $20 \mathrm{~mA}$ constant current. Some aliquots $(30 \mu \mathrm{l})$ were deglycosylated by incubation overnight at $37^{\circ} \mathrm{C}$ with $\mathrm{N}$-glycosidase $\mathrm{F}$ (0.5 unit). The proteins were transferred to Westran PVDF membranes for $3 \mathrm{~h}$ at $35 \mathrm{~mA}$ constant current and incubated for $1 \mathrm{~h}$ with anti-FLAG antibody or specific anti- $\mathrm{G}_{i} \alpha_{2}$ monoclonal antibody generated against the purified recombinant $\mathrm{G}_{i} \alpha_{2}$ subunit. The Western blot was developed using the enhanced chemiluminescence $\left(\mathrm{ECL}^{\mathbb{B}}\right.$, Amersham) method with sheep anti-mouse IgG antibody and developed by $30-60 \mathrm{~s}$ of exposure to Hyperfilm ECL auto- 
radiography film. For quantification of $\mathrm{G}_{i} \alpha_{2}$, developed films were scanned and integrated using Image Quant ${ }^{\mathrm{TM}}$ software. Preliminary experiments using purified $\mathrm{G}_{i} \alpha_{2}$ as standards have established that the signals generated under our working conditions were within the linear range. In some cases, SDS/ polyacrylamide gels were stained for protein [15].

\section{Radioligand binding assays}

Binding assays were performed using $\mathrm{A}_{1}$-selective radioligands, the agonist ${ }^{125} \mathrm{I}-\mathrm{ABA}$ and the antagonist, $\left[{ }^{3} \mathrm{H}\right] \mathrm{CPX}$, in the presence of 1.5 unit $/ \mathrm{ml} \mathrm{ADA}$ and $0.006 \%$ digitonin (for purified receptor only) with or without $4.9 \mathrm{mM} \mathrm{MgCl}_{2}$ for agonist and antagonist binding respectively. Non-specific binding was measured in the presence of $1 \mu \mathrm{M}$ CPX.

\section{Down-regulation of $H / F-A_{1} A R$}

CHO-K1 cells expressing H/F-A AR were pretreated with either vehicle (DMSO) or $20 \mu \mathrm{M} \mathrm{CPA}$ in the presence of $0.5 \mathrm{unit} / \mathrm{ml}$ ADA for various times, as indicated. Radioligand binding, membrane preparation, $\mathrm{R}-\mathrm{G}$ complex solubilization and purification were performed as described above. Differences in the time courses of agonist and antagonist down-regulation of receptor number were evaluated as described by Motulsky and Ransnas [16]. This procedure determines if two data sets are significantly better fitted to two curves or to a single curve.

\section{RESULTS}

\section{Affinity purification of G-protein-coupled and uncoupled H/F-A ARs}

The purification of $\mathrm{H} / \mathrm{F}-\mathrm{A}_{1} \mathrm{ARs}$ by sequential anti-FLAG antibody and Ni-NTA affinity chromatography results in a good yield of very highly purified receptors, as described previously [9]. In the present study, we sought to identify conditions optimal for the purification of receptors that are coupled to G-proteins $(\mathrm{R}-\mathrm{G})$ and receptors uncoupled from $\mathrm{G}$-proteins $(\mathrm{R})$. Uncoupling was achieved by pretreating membranes with GTP before receptor solubilization and purification. According to the "ternary complex' model, GTP or GTP analogues uncouple receptors from G-proteins [17]. The addition of $10 \mathrm{mM} \mathrm{GTP} \mathrm{to} \mathrm{membranes}$ almost completely abolished subsequent co-purification of $\mathrm{G}$ proteins with $\mathrm{H} / \mathrm{F}-\mathrm{A}_{1} \mathrm{ARs}$ from affinity columns. Figure 1(A) shows silver-stained $\mathrm{SDS} /$ polyacrylamide gels of $\mathrm{R}$ and $\mathrm{R}-\mathrm{G}$ purified by sequential anti-FLAG and $\mathrm{Ni}^{2+}$-NTA affinity columns. Upon treatment with $\mathrm{N}$-glycosidase $\mathrm{F}$, the diffuse $\mathrm{H} / \mathrm{F}$ $\mathrm{A}_{1} \mathrm{AR}$ shifts from an apparent molecular mass of $38-42 \mathrm{kDa}$ to $33-34 \mathrm{kDa}$, and the same shift in mass is detected in receptors photoaffinity-labelled with the xanthine ${ }^{125} \mathrm{I}$-azido-BW-A844 (Figure 1C) or by Western blotting receptors using anti-FLAG antibodies (Figure 1D). Some purified receptors form aggregates which appear as $94-98 \mathrm{kDa}$ (non-deglycosylated) and $66 \mathrm{kDa}$ (deglycosylated) proteins respectively by silver staining, photoaffinity labelling and Western blotting. The receptors are highly purified, but there are some additional proteins that can be weakly stained with silver that are co-purified. The most abundant of these is an unidentified $97 \mathrm{kDa}$ protein that was copurified with $\mathrm{R}$ or with $\mathrm{R}-\mathrm{G}$ (Figure 1A). Deglycosylation of purified $\mathrm{R}-\mathrm{G}$ complexes also reveals 42 and $35 \mathrm{kDa}$ proteins that are far less abundant in the $\mathrm{R}$ lane. These correspond in size to G-protein $\alpha$ and $\beta$ subunits respectively (Figure 1A, lane 4). $\mathrm{G}_{i} \alpha 2$ immunoreactivity co-migrates with the $42 \mathrm{kDa}$ protein found in purified R-G complexes, but not with uncoupled receptors (Figure 1B). By subjecting untagged (lacking $\mathrm{His}_{6}$ and FLAG) $\mathrm{A}_{1} \mathrm{ARs}$ to the purification protocol we established that there is no non-specific binding of receptors, G-proteins or the $97 \mathrm{kDa}$
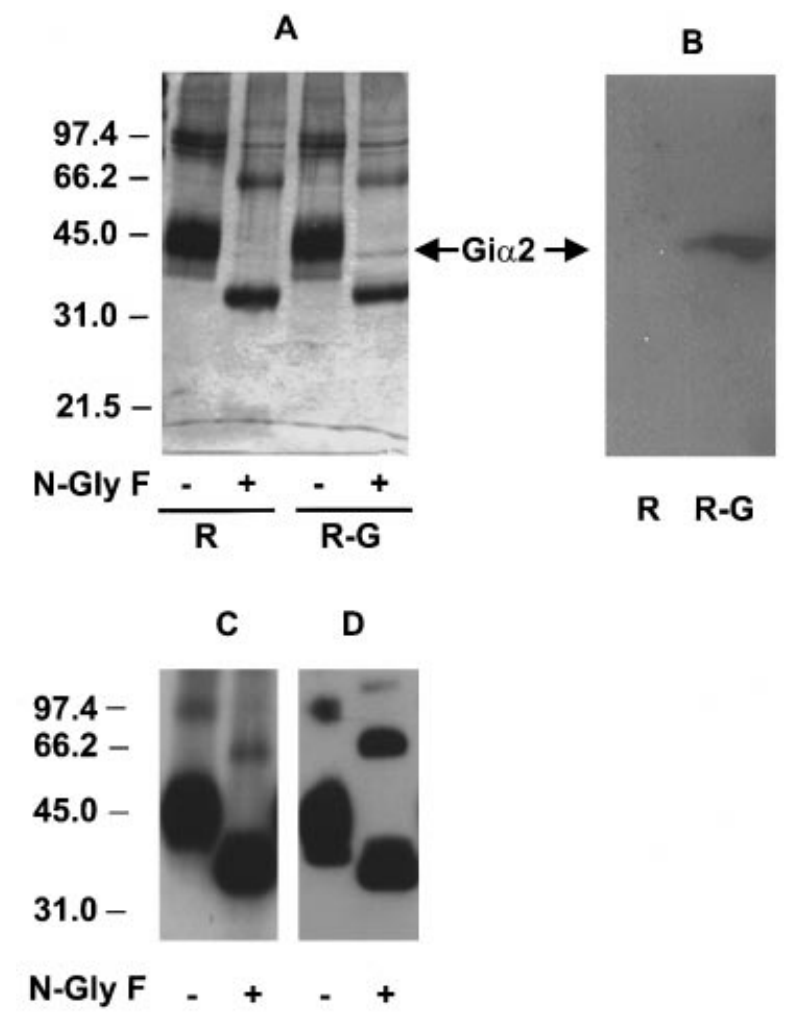

Figure 1 Silver-stained SDS/PAGE and Western analysis of purified H/F$A_{1} A R s$ without (R) or with $(R-G)$ associated G-proteins

$\mathrm{H} / \mathrm{F}-\mathrm{A}_{1} \mathrm{AR}$ derived from $70 \mathrm{mg}$ of $\mathrm{CHO}-\mathrm{K} 1$ membranes pretreated with or without $10 \mathrm{mM}$ GTP were solubilized and purified through sequential affinity-chromatography columns (anti-FLAG and Ni-NTA) as described in the Experimental section. (A) Aliquots containing 5.3\% of the purified receptors free of $G$-proteins (R) or $R-G$ complexes were resolved by SDS/PAGE, incubated with or without N-glycosidase $\mathrm{F}$ (N-Gly F), and stained with silver. (B) Western blots of $G_{i} \alpha 2$ in $1 \%$ of the $R$ and $R-G$ purified fractions. (C) Autoradiograph of purified photoaffinitylabelled H/F-A ARs. (D) Western analysis of purified H/F-A AR using anti-FLAG m2 antibody.

protein to the affinity-chromatography columns (results not shown). From these experiments we conclude that $\mathrm{H} / \mathrm{F}-\mathrm{A}_{1} \mathrm{ARs}$ can be purified by sequential anti-FLAG and Ni-NTA affinity columns either as pure receptors or as a mixture of uncoupled receptors and $\mathrm{R}-\mathrm{G}$ complexes from membranes pretreated with or without GTP respectively. Furthermore, there is no nonspecific purification of proteins that are not associated with $\mathrm{H} / \mathrm{F}$ $\mathrm{A}_{1}$ ARs.

Table 1 summarizes the recovery and specific activity of $\mathrm{H} / \mathrm{F}$ $\mathrm{A}_{1} \mathrm{AR}-\mathrm{G}$-protein complexes during affinity chromatography. We found that purified $\mathrm{R}-\mathrm{G}$ complexes have a specific activity (antagonist $\left[{ }^{3} \mathrm{H}\right] \mathrm{CPX}$-binding sites) of $5 \mathrm{nmol} / \mathrm{mg}$, which is $20 \%$ of the theoretical specific activity for a homogeneous $38 \mathrm{kDa}$ $\mathrm{H} / \mathrm{F}-\mathrm{A}_{1} \mathrm{AR}$. This specific activity is less than theoretical, owing to the presence of G-proteins, the $97 \mathrm{kDa}$ protein, other minor contaminants, and receptors that are denatured during solubilization and purification. The coupling between receptors and Gproteins [calculated as the ratio of high-affinity agonist- $\left[{ }^{125} \mathrm{I}-\right.$ $\mathrm{ABA}]$ to $\left[{ }^{3} \mathrm{H}\right] \mathrm{CPX}$-binding sites) is similar throughout the purification process, suggesting that the $\mathrm{R}-\mathrm{G}$ complexes are stable following detergent solubilization.

We have previously demonstrated that extension of the $\mathrm{N}$ termini of ARs with $\mathrm{His}_{6}$ and the FLAG epitope has no effect on the binding affinity of ligands, the coupling of receptors to G- 
Table 1 Purification of H/F-A AR-G-protein complexes

\begin{tabular}{|c|c|c|c|c|c|c|c|c|c|c|c|c|}
\hline & \multicolumn{6}{|c|}{$\left[{ }^{3} \mathrm{H}\right] \mathrm{CPX}$} & \multicolumn{6}{|c|}{${ }^{125} \mid-A B A$} \\
\hline & $\begin{array}{l}\text { Protein } \\
(\mathrm{mg})\end{array}$ & $\begin{array}{l}K_{D} \\
(n M)\end{array}$ & $\begin{array}{l}\text { Total receptor } \\
\text { (pmol) }\end{array}$ & $\begin{array}{l}\text { Specific activity } \\
\text { (pmol/mg) }\end{array}$ & $\begin{array}{l}\text { Yield } \\
(\%)\end{array}$ & $\begin{array}{l}\text { Purification } \\
\text { (fold) }\end{array}$ & $\begin{array}{l}K_{D} \\
(n M)\end{array}$ & $\begin{array}{l}\text { Total R-G } \\
\text { complexes } \\
\text { (pmol) }\end{array}$ & $\begin{array}{l}\text { Specific activity } \\
\text { (pmol/mg) }\end{array}$ & $\begin{array}{l}\text { Yield } \\
(\%)\end{array}$ & $\begin{array}{l}\text { Purification } \\
\text { (fold) }\end{array}$ & $\%$ Coupled \\
\hline Membrane & 90.3 & 2.80 & 2070 & 23.0 & 100 & 1 & 1.0 & 266.4 & 2.95 & 100 & 1 & 12.8 \\
\hline Solubilization & 35.6 & 14.0 & 911 & 25.6 & 44 & 1.11 & 0.9 & 79.4 & 2.23 & 29.8 & 0.76 & 8.7 \\
\hline FLAG elution & 0.12 & 14.8 & 530 & 4417 & 25.6 & 191 & 0.9 & 55.3 & 512 & 20.7 & 174 & 11.6 \\
\hline Ni-NTA elution & 0.09 & 14.8 & 438 & 4815 & 21 & 209 & 0.9 & 51.8 & 569.8 & 19.4 & 193 & 11.8 \\
\hline
\end{tabular}

Table 2 Summary of $K_{1}$ values of compounds to compete for radioligand binding to membranes and affinity purified recombinant $H / F-A_{1} A R-G-p r o t e i n$ complexes

${ }^{125}$-ABA was used as the radioligand. Values are means \pm S.E.M. Agonists are indicated by italics. $K_{1}$ values for agonists reflect high-affinity binding sites. $h$ is the Hill coefficient.

\begin{tabular}{|c|c|c|c|c|c|c|}
\hline \multirow[b]{2}{*}{ Competitor } & \multicolumn{3}{|l|}{ Purified $R-G$} & \multicolumn{3}{|l|}{ Membrane* } \\
\hline & $K_{1}(\mathrm{nM})$ & $h$ & $n$ & $K_{1}(\mathrm{nM})$ & $h$ & $n$ \\
\hline $\mathrm{CPX}\left(\mathrm{K}_{\mathrm{D}}\right)$ & $14.8+1.8$ & $1.13+0.08$ & 5 & $2.8+0.6$ & $1.17+0.14$ & 3 \\
\hline XAC & $122 \pm 15$ & $1.12 \pm 0.06$ & 3 & $50.6 \pm 7.0$ & $0.96 \pm 0.08$ & 5 \\
\hline 8-SPT & $6460 \pm 40$ & $1.07 \pm 0.02$ & 3 & $6210 \pm 2580$ & $0.84 \pm 0.06$ & 3 \\
\hline$C P A$ & $1.00 \pm 0.08$ & $1.01 \pm 0.06$ & 4 & $0.31 \pm 0.08$ & $0.79 \pm 0.02$ & 3 \\
\hline$N E C A$ & $1.06 \pm 0.13$ & $0.91 \pm 0.14$ & 4 & $1.27 \pm 0.36$ & $0.97 \pm 0.06$ & 5 \\
\hline CGS21680 & $154 \pm 13$ & $0.95 \pm 0.05$ & 6 & $416 \pm 130$ & $0.96 \pm 0.07$ & 5 \\
\hline
\end{tabular}

proteins or the receptor-mediated changes in cyclic AMP accumulation [9]. Here we show that, with the exception of very hydrophobic ligands (CPX and CGS15943), which show decreased affinity for detergent-solubilized receptors, purified $\mathrm{H} / \mathrm{F}$ $\mathrm{A}_{1} \mathrm{ARs}$ have pharmacological properties similar to those in membranes (Table 2). The selective effect of detergent solubilization on hydrophobic compounds is most likely explained by differential partitioning of lipophilic ligands into membranes versus detergent solution. These data suggest that the purification of recombinant $\mathrm{H} / \mathrm{F}-\mathrm{A}_{1} \mathrm{ARs}$ by affinity chromatography results in functional receptors suitable for further studies of receptor structure and function.

\section{Effect of prolonged agonist-pretreatment on receptor-G-protein coupling}

$\mathrm{A}_{1} \mathrm{AR}$ desensitization has been extensively studied in transfected cells [18], isolated tissues [11,19] and whole animals [20]. In each case, chronic exposure of $\mathrm{A}_{1} \mathrm{AR}$ to agonists is manifested as a slow decrease in receptor-G-protein coupling and a gradual down-regulation of total receptor number. We examined agonistinduced down-regulation in $\mathrm{CHO}-\mathrm{K} 1$ cells stably transfected with $\mathrm{H} / \mathrm{F}-\mathrm{A}_{1} \mathrm{ARs}$. Intact cells were exposed to $20 \mu \mathrm{M}$ CPA for various times, as indicated in Figure 2. The total number of receptors on membranes was determined by measuring $\left[{ }^{3} \mathrm{H}\right] \mathrm{CPX}$ binding (Figure 2A), and the number of GCRs was determined by measuring high-affinity ${ }^{125} \mathrm{I}-\mathrm{ABA}$ binding (Figure 2B). Figure 2(C) shows the kinetics of down-regulation of both total receptor number and the number of GCRs during agonist exposure. The $t \frac{1}{2}$ for the down-regulation of agonist binding $(5.6 \mathrm{~h})$ is significantly lower than the $t \frac{1}{2}$ for the loss of antagonist binding
$(10.9 \mathrm{~h})$. After $24 \mathrm{~h}$ of exposure to CPA there is a similar fractional decrease in the number of agonist- and antagonistbinding sites detected on membranes, so the coupling ratio is minimally changed from control (Figure 2C).

We next sought to determine if down-regulation has any effect on the fraction of receptors that are purified as $\mathrm{R}-\mathrm{G}$ complexes. Following down-regulation for $24 \mathrm{~h}$ by exposing intact cells to $20 \mu \mathrm{M}$ CPA, receptors and $\mathrm{R}-\mathrm{G}$ complexes were purified by anti-FLAG affinity chromatography. The number of total receptors and $\mathrm{R}-\mathrm{G}$ complexes was determined from antagonist $\left(\left[{ }^{3} \mathrm{H}\right] \mathrm{CPX}\right)$ (Figure $\left.3 \mathrm{~A}\right)$ and high-affinity agonist $\left({ }^{125} \mathrm{I}-\mathrm{ABA}\right)$ binding (Figure $3 \mathrm{~B}$ ) respectively. Following down-regulation, there was a $47 \pm 6 \%$ decrease in the total number of receptors, and a similar $54 \pm 4 \%$ decrease in the number $R-G$ complexes measured in membranes. There was a similar decrease in the number of purified receptors, $54 \pm 6 \%$, but a substantially larger decrease in the number of purified R-G complexes, $78 \pm 3 \%$ (Figure 3C). These experiments reveal a novel aspect of agonistinduced down-regulation, namely a diminished stability of $\mathrm{R}-\mathrm{G}$ complexes that is manifested as $\mathrm{R}-\mathrm{G}$ uncoupling during receptor purification.

\section{Down-regulation decreases the amount of $G_{1} \alpha_{2}$ that is co-purified with H/F-A,AR}

We next sought to confirm that down-regulation decreases the amount of G-proteins that can be co-purified with $\mathrm{H} / \mathrm{F}-\mathrm{A}_{1} \mathrm{AR}$. Following $24 \mathrm{~h}$ of down-regulation of intact cells with $20 \mu \mathrm{M}$ $\mathrm{CPA}$, the same number of purified receptors from control and desensitized cells (based on $\left[{ }^{3} \mathrm{H}\right] \mathrm{CPX}$-binding sites and confirmed by Western analysis using anti-FLAG M2 antibody; results not shown) were subjected to SDS/PAGE followed by Western transfer. Co-purified $\mathrm{G}_{i} \alpha_{2}$ was quantified by Western analysis using a previously characterized monoclonal antibody [21] (results not shown). When normalized to receptor number, there is a $50 \%$ decrease in $\mathrm{G}_{i} \alpha_{2}$ following down-regulation. Taking into account the $54 \%$ decrease in the total number of receptors purified from agonist-treated cells, the overall decrease of $G_{i} \alpha 2$ co-purified with desensitized receptors was calculated as $74 \%$, which is comparable with the $78 \%$ decrease in ${ }^{125} \mathrm{I}-\mathrm{ABA}$ binding sites noted above. These data are consistent with the expectation that decreased high-affinity agonist binding following downregulation reflects a decrease in the amount of G-proteins copurified with receptors.

\section{Phosphorylation of H/F-A AR}

For many GCRs, receptor phosphorylation results in uncoupling from G-proteins and functional desensitization. We set out to determine whether $\mathrm{H} / \mathrm{F}-\mathrm{A}_{1} \mathrm{ARs}$ can be phosphorylated and 

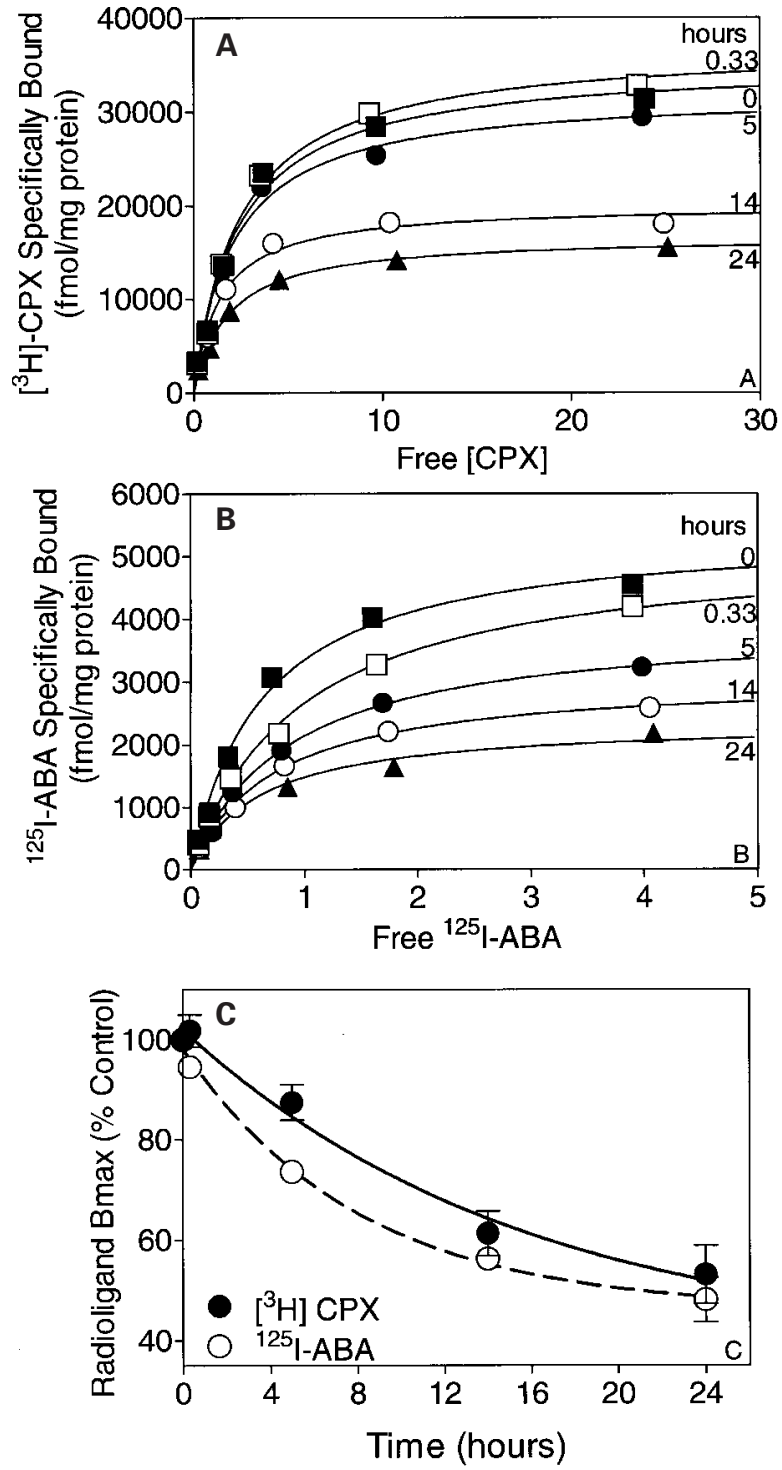

Figure 2 Down-regulation of radioligand binding to membranes from CHOK1 expressing H/F-A AR following treatment with CPA

Intact cells derived from a single confluent $150 \mathrm{~mm}$ plate were pretreated with $20 \mu \mathrm{M} \mathrm{CPA}$ in the presence of $0.5 \mathrm{unit} / \mathrm{ml} \mathrm{ADA}$ for the times indicated. After extensive washes, membranes were prepared and used for binding isotherms with $\left[{ }^{3} \mathrm{H}\right] \mathrm{CPX}(\mathbf{A})$ or ${ }^{125} \mathrm{I}-\mathrm{ABA}(\mathbf{B})$. The binding isotherms (A and $\mathbf{B}$ ) are representative of two independent experiments. The time-dependence of the loss in radioligand binding was pooled from two independent experiments each done in triplicate and fitted to mono-exponential equations $(\mathbf{C})$. The $t_{1}$ for the loss of binding was $5.6 \mathrm{~h}$ for ${ }^{125}$-IABA and $10.9 \mathrm{~h}$ for $\left.{ }^{3} \mathrm{H}\right] \mathrm{CPX}$. The time courses differed significantly $(P<0.05)$ (see the Experimental section).

whether phosphorylation is regulated by pretreatment of intact cells with an agonist or an antagonist. Transfected cells were metabolically labelled with $\left[{ }^{32} \mathrm{P}\right]$ phosphate and receptors were purified over anti-FLAG affinity columns. As shown in Figures 4(A) and 4(B), deglycosylation revealed a distinct, weakly phosphorylated protein with a molecular mass of $\approx 34 \mathrm{kDa}$, suggesting that this phosphoglycoprotein might be the $\mathrm{H} / \mathrm{F}$ $A_{1}$ AR. Without deglycosylation, receptor phosphorylation was not easily detected because of the diffuseness of glycosylated receptors and the existence of other weakly phosphorylated proteins, possibly including G-protein $\alpha$ and $\beta$ subunits. Several
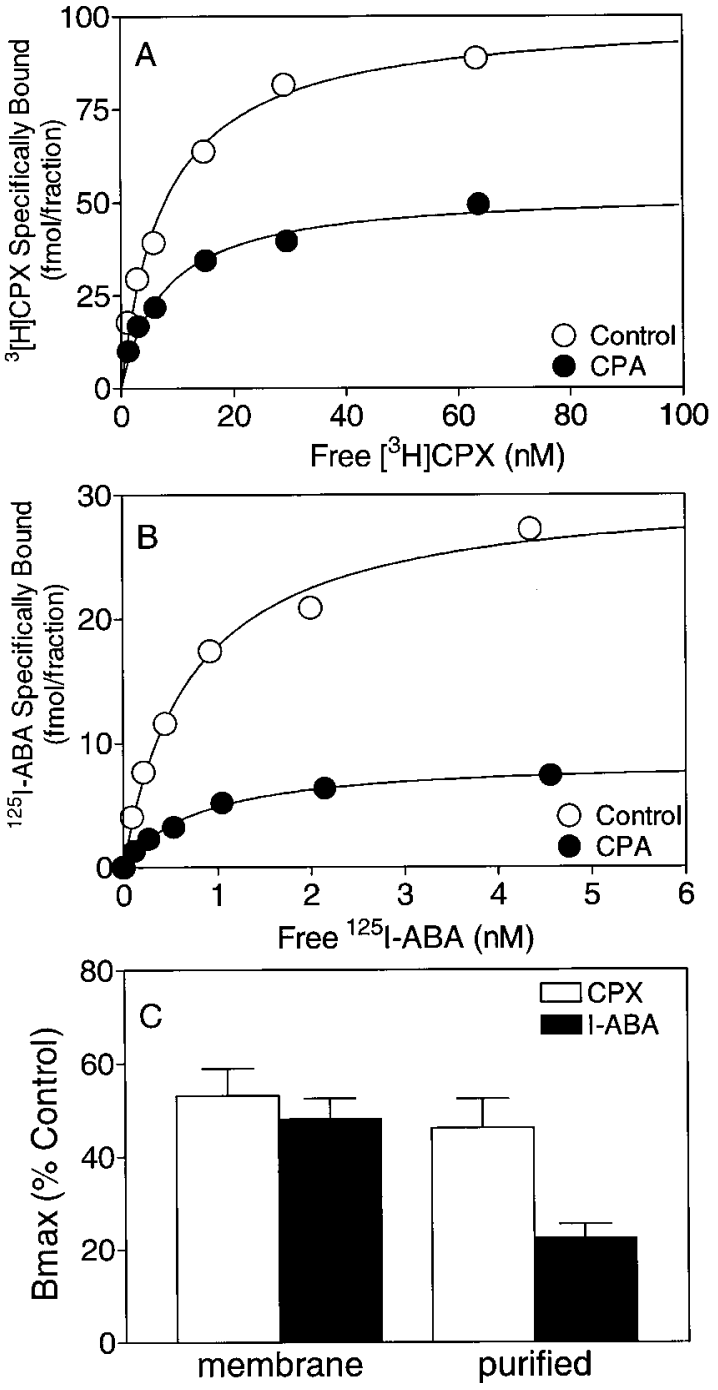

Figure 3 Effect of CPA-induced down-regulation on radioligand binding to purified H/F-A AR-G-protein complexes

Receptors were purified from 20 150-mm-diameter plates of $\mathrm{CHO}-\mathrm{K} 1$ cells expressing $\mathrm{H} / \mathrm{F}-\mathrm{A}_{1} \mathrm{AR}$ and pretreated with either vehicle or $20 \mu \mathrm{M} \mathrm{CPA}$ for $24 \mathrm{~h}$. (A) and (B) show typical equilibrium binding isotherms for the antagonist, $\left[{ }^{3} \mathrm{H}\right] \mathrm{CPX}$, and the agonist, ${ }^{125} \mathrm{I}$-ABA, respectively. S.E.M. bars are smaller than the symbols. Each fraction contains $4 \mu \mathrm{l}$ from $2 \mathrm{ml}$ of purified $\mathrm{R}-\mathrm{G}$ complexes. (C) Comparison of CPA-induced down-regulation (24 h) of $\left[{ }^{3} \mathrm{H}\right] \mathrm{CPX}$ and ${ }^{125}$-ABA binding to $H / F-A, A R$ measured in membranes or purified $R-G$ complexes. Data are normalized to specific binding sites in membranes or purified from control cells in parallel experiments. Specific-binding data are means \pm S.E.M. $(n=3)$.

high-molecular-mass phosphoproteins also were detected by autoradiography, including a $97 \mathrm{kDa}$ phosphoprotein. Prolonged antagonist or agonist $(12 \mathrm{~h})$ pretreatment did not significantly alter the amount of $\left[{ }^{32} \mathrm{P}\right]$ phosphate incorporated into the receptors, G-proteins or the $97 \mathrm{kDa}$ protein. Phosphoamino acid analysis indicated that $\mathrm{H} / \mathrm{F}-\mathrm{A}_{1} \mathrm{ARs}$ are phosphorylated predominantly on serine residue(s), with a very low level of phosphothreonine; no phosphotyrosine was detected (Figure 4C). These data suggest that $\mathrm{H} / \mathrm{F}-\mathrm{A}_{1} \mathrm{ARs}, \mathrm{G}$-protein $\alpha$ - and $\beta$ subunits, as well as the $97 \mathrm{kDa}$ protein, are constitutively and weakly phosphorylated in transfected cells and that the amount of phosphorylation is not changed by exposure to CPA. 
(A)

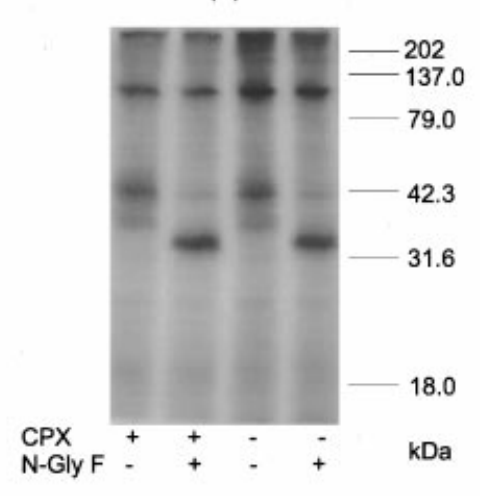

(B)

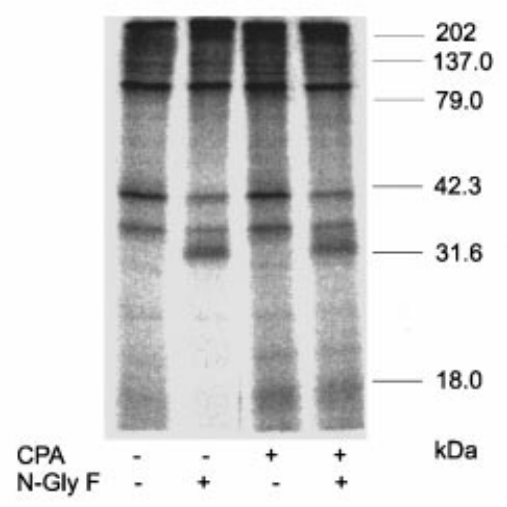

Figure 4 Phosphorylation of H/F-A AR

One confluent 100-mm-diameter plate of transfected $\mathrm{CHO}-\mathrm{K} 1$ cells expressing 25-35 pmol/mg of protein of recombinant human $\mathrm{H} / \mathrm{F}-\mathrm{A}_{1} \mathrm{AR}$ was preincubated with $4 \mathrm{mCi}$ of $\left.{ }^{32} \mathrm{P}\right]$ phosphate in phosphate-free DMEM medium for $2 \mathrm{~h} ; 1 \mu \mathrm{M}$ CPX (A) or $10 \mu \mathrm{M}$ CPA (B) was added for an additional of $12 \mathrm{~h}$. Receptors were purified as described in the Experimental section and were subject to SDS/PAGE without $(-)$ or with $(+)$ prior treatment with $\mathrm{N}$-glycosidase $\mathrm{F}$ (N-Gly F). (C) Phosphoamino acid analysis of purified deglycosylated ${ }^{32} \mathrm{P}$-labelled $\mathrm{H} / \mathrm{F}-\mathrm{A}_{1} \mathrm{AR}$. Abbreviations: pS, phosphoserine; pT, phosphothreonine; pY, phosphotyrosine.

\section{DISCUSSION}

In the present study we have examined factors that control receptor desensitization and the coupling of receptors to Gproteins using purified recombinant human $\mathrm{A}_{1} \mathrm{ARs}$ that have been modified to facilitate their purification. We show that either uncoupled receptors or receptors that are partially coupled to Gproteins can be purified under conditions which preserve their ability to bind radioligands.

Our data suggest that recombinant human $\mathrm{A}_{1} \mathrm{ARs}$ can only undergo long-term (slow) desensitization following exposure to an agonist (Figure 2). Interestingly, during this process, there is a significantly faster decrease in the number of high affinity $\mathrm{A}_{1} \mathrm{AR}$ binding sites for the agonist, ${ }^{125} \mathrm{I}-\mathrm{ABA}$, than for the antagonist, $\left[{ }^{3} \mathrm{H}\right] \mathrm{CPX}$, (Figure 2). Agonist binding may diminish more quickly than antagonist binding because the loss of agonist binding results from both decreased coupling of receptors to Gproteins and from down-regulation of receptor number, whereas antagonist binding primarily reflects receptor number and is only slightly affected by receptor coupling to G-proteins. A comparison of the number of receptors and $\mathrm{R}-\mathrm{G}$ complexes purified from control and desensitized cells indicates that long-term exposure of intact cells to an agonist results in a weakened interaction between receptors and G-proteins and facilitates uncoupling during the solubilization and purification process. The destabilizing effect of prolonged agonist exposure on $\mathrm{R}-\mathrm{G}$ complexes is manifested as a decrease in the fraction of purified receptors that can bind ${ }^{125} \mathrm{I}-\mathrm{ABA}$ (presumed $\mathrm{R}-\mathrm{G}$ complexes), and decreased amounts of $\mathrm{G}_{i} \propto 2$ co-purified with receptors. It is noteworthy that this destabilization is not accompanied by a change in the phosphorylation state of receptors, the phosphorylation state of co-purified G-protein $\alpha$ - and $\beta$ - subunits or the $97 \mathrm{kDa}$ protein. These findings imply that there is an unknown factor or factors that regulate(s) the affinity of the interaction between the $A_{1} A R s$ and G-proteins.

Searching for factors that modulate $\mathrm{R}-\mathrm{G}$ coupling is an area of intense current interest, and several proteins that regulate coupling have been identified. These include arrestin [22], phosducin [23], recoverin [24] and regulators of G-protein signalling ('RGSs') [25]. In the case of the $\mathrm{A}_{1} \mathrm{AR}$, a putative 'coupling cofactor' partially purified from cortical brain membranes $(\approx 150 \mathrm{kDa})$ was reported to stabilize $\mathrm{A}_{1} \mathrm{AR}-\mathrm{G}$-protein complexes and to trap the $\mathrm{A}_{1} \mathrm{AR}$ in a high-affinity agonistbinding state [26]. Removal of this protein from membranes was reported to increase the sensitivity of high-affinity agonist binding to inhibition by GTP[S], resulting in weakened $\mathrm{R}-\mathrm{G}$ coupling

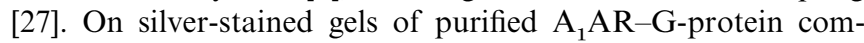
plexes we did not detect co-purified proteins corresponding to the molecular masses of these various factors. This would suggest that the regulation of the interaction between receptors and G-proteins is the result of a modification of the receptor itself, a G-protein or the $97 \mathrm{kDa}$ protein that was co-purified with receptors.

Phosphorylation of receptors secondary to agonist exposure by either GCR kinases (GRKs) or second-messenger-activated protein kinases, such as protein kinases $A$ and kinase $C$, has been reported to influence the stability of various $\mathrm{R}-\mathrm{G}$ complexes, and have been implicated in both short-term uncoupling and desensitization processes. Receptor phosphorylation by a GRK promotes the binding of one of four arrestin family members to agonist-occupied receptor molecules that are engaged in Gprotein activation [28]. However, endogenous levels of GRKs are sufficient to phosphorylate some G-protein-coupled receptors more efficiently than others. For example, human endothelin A and B receptors overexpressed in HEK-293 cells undergo rapid agonist-induced phosphorylation and desensitization, and these effects are only somewhat enhanced by overexpression of GRKs [28,29]. In contrast, desensitization of the chemokine receptor CCR-5 does not occur at all in HEK-293 cells in the absence of GRK overexpression [30]. $\alpha$-Adrenergic receptor subtypes display different rates of phosphorylation and desensitization. Unlike the $\alpha 2 \mathrm{C} 10$ adrenergic receptor, the $\alpha 2 \mathrm{C} 4$ receptor is not phosphorylated by any of the GRKs and does not undergo rapid agonist-induced desensitization when overexpressed in HEK-293 cells [13]. Mutant $\mathrm{m} 2$ muscarinic receptors that can not be phosphorylated in an agonist-dependent manner also do not display rapid desensitization [31]. Hence, there are substantial differences in the susceptibility of various GCRs to phosphorylation by GRKs and correlated differences in rapid agonistinduced desensitization.

$\mathrm{A}_{1}$ ARs do not undergo rapid agonist-induced desensitization. In transfected $\mathrm{CHO}-\mathrm{K} 1$ cells, Palmer et al. [32] could not detect rapid $(10 \mathrm{~min})$ agonist-stimulated $\mathrm{A}_{1} \mathrm{AR}$ phosphorylation. In parallel experiments, recombinant $\mathrm{A}_{3} \mathrm{ARs}$ displayed substantial agonist-stimulated phosphorylation and desensitization. These findings agree with the results of the present study and suggest that the $A_{1} A R$ belongs to a subset of GCRs that are not substrates or are poor substrates for GRKs and do not undergo 
rapid desensitization. Teleologically, $\mathrm{A}_{1} \mathrm{ARs}$ may be resistant to acute agonist-dependent phosphorylation because adenosine receptors protect excitable tissues from ischaemia, and this protective response may have evolved to be resistant to rapid and large-scale desensitization characteristic of certain other GCRs, including the $\mathrm{A}_{3} \mathrm{AR}$ [32].

In the present study we have examined the effect of prolonged agonist exposure on $A_{1} A R$ phosphorylation, $R-G$ coupling and desensitization. The role of receptor phosphorylation in the longterm desensitization has been examined in only a limited number of studies. Phosphorylation of $\beta_{2}$-adrenergic receptors by protein kinase A regulates the rate and extent of agonist-induced receptor down-regulation. Mcgraw et al. [33] recently demonstrated persistent phosphorylation of $\beta 2$-adrenergic receptors by GRK during 24 h of exposure to an agonist. Removal of the GRK phosphorylation sites attenuates, but does not abolish, long-term desensitization. In the case of M3 muscarinic receptors, a threonine residue in the $\mathrm{C}$-terminal tail appears to regulate the rate of long-term receptor down-regulation [34]. The results of the present study indicate that long-term down-regulation of the $\mathrm{A}_{1} \mathrm{AR}$ and destabilization of $\mathrm{R}-\mathrm{G}$ complexes can occur in the absence of a change in the receptor phosphorylation state. This supports the notion that phosphorylation may in some instances modulate, but is not required for, receptor down-regulation.

There is conflicting prior literature regarding agonist-induced phosphorylation and desensitization of $A_{1} A R s$. Partially purified receptors were reported to undergo rapid (5 $\mathrm{min}$ ) [35] or slow $(18 \mathrm{~h})$ agonist-stimulated phosphorylation [36]. However, in this type of experiment it may be difficult to distinguish minor contaminating ${ }^{32} \mathrm{P}$-labelled phosphoproteins from phosphorylated receptors in instances in which receptors are impure. This point is illustrated in Figure 4. Phosphorylated receptors cannot be resolved from contaminating non-receptor phosphoproteins unless they are deglycosylated. Using deglycosylation to confirm the identity of the putative receptor phosphoprotein has not been used in previous studies, such as in the study by Ciruela et al. [35], who reported that native $\mathrm{A}_{1} \mathrm{ARs}$ partially purified by immunoprecipitation from $\mathrm{DDT}_{1} \mathrm{MF}_{2}$ cells display a $>7$-fold increase in $\left[{ }^{32} \mathrm{P}\right]$ phosphotyrosine into a $36 \mathrm{kDa}$ putative receptor within minutes. These results are surprising in view of studies which show that desensitization of $\mathrm{A}_{1} \mathrm{ARs}$ on $\mathrm{DDT}_{1} \mathrm{MF}_{2}$ cells takes several hours [36]. Moreover, in the present study we found no incorporation of ${ }^{32} \mathrm{P}$ into receptor tyrosine; rather the lowlevel phsophorylation of $\mathrm{A}_{1} \mathrm{ARs}$ that was observed was predominantly on serine residues. Using transfected CHO-K1 cells, Palmer et al. were not able to detect any rapid agonist-induced phosphorylation of $A_{1} A R s$ [32]. Given the great discrepancies in the literature regarding $\mathrm{A}_{1} \mathrm{AR}$ phosphorylation, we believe that deglycosylation is a useful and important method to unequivocally identify poorly phosphorylated receptors.

In addition to receptor phosphorylation, another potential mechanism of regulating the stability of $\mathrm{R}-\mathrm{G}$ complexes is via phosphorylation of G-proteins. $G_{i} \alpha 2$, but not $G_{i} \propto 3$ from hepatocytes, was found to be phosphorylated on serine residues by protein kinase $\mathrm{C}$ both in vivo and in vitro [37-39]. Elevated phosphorylation of $\mathrm{G}_{i} \propto 2$ was correlated with decreased ability to inhibit adenylate cyclase $[40,41]$. Tyrosine phosphorylation of $\mathrm{G}_{\mathrm{q}} \propto$ [42], $\mathrm{G}_{\mathrm{s}} \alpha$ [43] and functional consequences have also been reported. $\mathrm{G} \beta$ also has been reported to be regulated by phosphorylation $[44,45]$. One possibility that is consistent with our data is that phosphorylation of G-proteins causes them to become uncoupled from receptors, in which case the phosphorylated G-proteins would not be purified as R-G complexes.

Another possible mode of regulating $\mathrm{R}-\mathrm{G}$ coupling that we did not explore in the present study is that the phosphorylation state of the $\gamma$ subunit of heterotrimeric G-proteins influences coupling to receptors. Our gels were run under conditions that were not designed to retain the small $\gamma$ subunits. The $\gamma 12$ subunit is phosphorylated by protein kinase $\mathrm{C}$ in response to activation of various GCRs [46]. Recently, the phosphorylation of $\gamma 12$ by protein kinase $\mathrm{C}$ was reported to increase the stability of $\mathrm{A}_{1} \mathrm{AR}-\mathrm{G}$-protein complexes [47]. To be consistent with the results of the present study, long-term exposure to an agonist would decrease the phosphorylation of $\gamma 12$ to destabilize $\mathrm{R}-\mathrm{G}$ complexes. It is also possible that, during long-term exposure to an agonist, there is a change in the complement of G-protein $\beta \gamma$ subunits associated with receptors. Finally, additional unknown modifications of receptors or G-proteins other than phosphorylation may play a role in influencing the stability of $R-G$ complexes.

This work was supported by grant no. R0137942 from the National Institutes of Health. We thank Dr. James Garrison for helpful discussions.

\section{REFERENCES}

1 Munshi, R. and Linden, J. (1989) J. Biol. Chem. 264, 14853-14859

2 Munshi, R., Pang, I. H., Sternweis, P. C. and Linden, J. (1991) J. Biol. Chem. 266 22285-22289

3 Luthin, D. R., Eppler, C. M. and Linden, J. (1993) J. Biol. Chem. 268, 5990-5996

4 Polakis, P. G., Uhing, R. J. and Snyderman, R. (1988) J. Biol. Chem. 263 4969-4976

5 Georgoussi, Z., Milligan, G. and Zioudrou, C. (1995) Biochem. J. 306, 71-75

6 Matesic, D. F., Manning, D. R., Wolfe, B. B. and Luthin, G. R. (1989) J. Biol. Chem. 264, 21638-21645

7 Wennogle, L. P., Conder, L., Winter, C., Braunwalder, A., Vlattas, S., Kramer, R., Cioffi, C. and Hu, S. I. (1994) J. Cell Biochem. 55, 380-388

8 Zhang, J. and Pratt, R. E. (1996) J. Biol. Chem. 271, 15026-15033

9 Robeva, A. S., Woodard, R., Luthin, D. R., Taylor, H. E. and Linden, J. (1996) Biochem. Pharmacol. 51, 545-555

10 Linden, J., Jacobson, M. A., Hutchins, C. and Williams, M. (1994) in Handbook of Receptors and Channels: G-Protein Coupled Receptors (Peroutka, S. J., ed.), pp. 29-44, CRC Press, Boca Raton, FL

11 Shryock, J., Patel, A., Belardinelli, L. and Linden, J. (1989) Am. J. Physiol. 256, H321-H327

12 Freedman, N. J. and Lefkowitz, R. J. (1996) Recent Prog. Horm. Res. 51, 319-351

13 Jewell-Motz, E. A. and Liggett, S. B. (1996) J. Biol. Chem. 271, 18082-18087

14 Linden, J., Patel, A. and Sadek, S. (1985) Circ. Res. 56, 279-284

15 Morrissey, J. H. (1981) Anal. Biochem. 117, 307-310

16 Motulsky, H. J. and Ransnas, L. A. (1987) FASEB J. 1, 365-374

17 Limbird, L. E., Gill, D. M. and Lefkowitz, R. J. (1980) Proc. Natl. Acad. Sci. U.S.A. 77, 775-779

18 Bhattacharya, S. and Linden, J. (1996) Mol. Pharmacol. 50, 104-111

19 Parsons, W. J. and Stiles, G. L. (1987) J. Biol. Chem. 262, 841-847

20 Dennis, D. M., Shryock, J. C. and Belardinelli, L. (1995) J. Pharmacol. Exp. Ther. 272, 1024-1035

21 Luthin, D. R., Eppler, C. M. and Linden, J. (1993) J. Biol. Chem. 268, 5990-5996

22 Ferguson, S. S., Barak, L. S., Zhang, J. and Caron, M. G. (1996) Can. J. Physiol. Pharmacol. 74, 1095-1110

23 Wehmeyer, A. and Schulz, R. (1998) Life Sci. 62, L127-L134

24 Faurobert, E., Chen, C. K., Hurley, J. B. and Teng, D. H. (1996) J. Biol. Chem. 271 10256-10262

25 Dohlman, H. G. and Thorner, J. (1997) J. Biol. Chem. 272, 3871-3874

26 Nanoff, C., Waldhoer, M., Roka, F. and Freissmuth, M. (1997) Neuropharmacology 36, 1211-1219

27 Nanoff, C., Mitterauer, T., Roka, F., Hohenegger, M. and Freissmuth, M. (1995) Mol. Pharmacol. 48, 806-817

28 Freedman, N. J., Ament, A. S., Oppermann, M., Stoffel, R. H., Exum, S. T. and Lefkowitz, R. J. (1997) J. Biol. Chem. 272, 17734-17743

29 Freedman, N. J., Liggett, S. B., Drachman, D. E., Pei, G., Caron, M. G. and Lefkowitz, R. J. (1995) J. Biol. Chem. 270, 17953-17961

30 Aramori, I., Zhang, J., Ferguson, S. S., Bieniasz, P. D., Cullen, B. R. and Caron, M. G. (1997) EMBO. J. 16, 4606-4616

31 Pals-Rylaarsdam, R., Xu, Y., Witt-Enderby, P., Benovic, J. L. and Hosey, M. M. (1995) J. Biol. Chem. 270, 29004-29011

32 Palmer, T. M., Benovic, J. L. and Stiles, G. L. (1996) J. Biol. Chem. 271, 15272-15278 
33 McGraw, D. W., Donnelly, E. T., Eason, M. G., Green, S. A. and Liggett, S. B. (1998) Cell. Signal. 10, 197-204

34 Yang, J., Logsdon, C. D., Johansen, T. E. and Williams, J. A. (1993) Mol. Pharmacol. 44, 1158-1164

35 Ciruela, F., Saura, C., Canela, E. I., Mallol, J., Lluis, C. and Franco, R. (1997) Mol. Pharmacol. 52, 788-797

36 Ramkumar, V., Olah, M. E., Jacobson, K. A. and Stiles, G. L. (1991) Mol. Pharmacol. 40, 639-647

37 Morris, N. J., Bushfield, M., Lavan, B. E. and Houslay, M. D. (1994) Biochem. J. 301, 693-702

38 Bushfield, M., Lavan, B. E. and Houslay, M. D. (1991) Biochem. J. 274, 317-321

39 Bushfield, M., Murphy, G. J., Lavan, B. E., Parker, P. J., Hruby, V. J., Milligan, G. and Houslay, M. D. (1990) Biochem. J. 268, 449-457

40 Strassheim, D. and Malbon, C. C. (1994) J. Biol. Chem. 269, 14307-14313

Received 17 August 1998/25 November 1998; accepted 18 December 1998
41 Bushfield, M., Griffiths, S. L., Murphy, G. J., Pyne, N. J., Knowler, J. T., Milligan, G., Parker, P. J., Mollner, S. and Houslay, M. D. (1990) Biochem. J. 271, 365-372

42 Liu, W. W., Mattingly, R. R. and Garrison, J. C. (1996) Proc. Natl. Acad. Sci. U.S.A. 93, 8258-8263

43 Hausdorff, W. P., Pitcher, J. A., Luttrell, D. K., Linder, M. E., Kurose, H., Parsons, S. J., Caron, M. G. and Lefkowitz, R. J. (1992) Proc. Natl. Acad. Sci. U.S.A. 89 5720-5724

44 Feng, Y., Song, L. Y., Kincaid, E., Mahanty, S. K. and Elion, E. A. (1998) Curr. Biol. 8, 267-278

45 Cole, G. M. and Reed, S. I. (1991) Cell 64, 703-716

46 Asano, T., Morishita, R., Ueda, H., Asano, M. and Kato, K. (1998) Eur. J. Biochem. 251, 314-319

47 Yasuda, H., Lindorfer, M. A., Myung, C.-S. and Garrison, J. C. (1998) J. Biol. Chem. 273, 21958-21965 